\title{
INCIDENCE OF NEUROSIS RELATED TO MATERNAL AGE AND BIRTH ORDER
}

\author{
BY \\ ALAN NORTON \\ From Bexley and Lewisham Hospitals
}

Order of birth and the strongly associated variable maternal age have often been investigated as possible determinants of a variety of congenital abnormalities. The work of Penrose (1934) and Malzberg (1950) on mongolism, and that of Still (1927) and McKeown, MacMahon, and Record (1951) on congenital pyloric stenosis has pointed to some of the difficulties.

Birth order has also frequently been examined in studies of intelligence, juvenile delinquency, psychosis, and epilepsy, and after allowance has been made for the pitfalls in such investigations a general impression remains of a handicapping of the first-born.

In psychiatric work, the emphasis shifts somewhat from the order of birth to the position in the family. This has long been looked upon as one of the influences moulding character. The schools of Freud and Adler in particular have always laid stress on this factor, and the tacit assumption has been made that it is also of aetiological importance in the production of mental and nervous disorder. If this is so, the decrease in mean family size from Victorian times to the present (from $5 \cdot 71$ to $2 \cdot 19$, vide Report of the Royal Commission on Population, 1949) may be important. Despite a wealth of anecdotal material there is a surprising paucity of recorded factual evidence.

The present investigation attempts to answer the question whether the incidence of neurosis is related to maternal age and order of birth. The incidence of neurotic illness in only children, and in youngest, intermediate, and eldest children in families with more than one child, is also examined, as is the association with father's age, age differences between parents, and loss of one or both parents.

Parts of this field have been surveyed in the last thirty years, particularly by Holmes (1921), Jones (1933), Thurstone and Jenkins (1931), Hsiao (1931), and Miller (1944), but much new material has been published since these reports were compiled.

\section{METHOD}

The investigation of the association between the incidence of neurosis and maternal age and birth order relies upon a comparison of a series of patients with a control group. Since information was obtained about size of family as well as about position in family, and since the sibships were presumably complete at the time of enquiry, the method of Greenwood and Yule (1914) is also used in examining the association of incidence with birth order.

(a) Patients.-A random sample of 500 patients of fifteen years of age or more attending the psychiatric department of a general hospital was chosen. Most were suffering from psychoneurosis or personality disorders. Patients with florid psychoses and organic mental disorder were excluded, but the series does contain a few mild endogenous depressives, accounting for less than 10 per cent. of the total. The information was in most cases provided by the patients themselves, but was given in some by a relative. There seems no reason to suppose that there is any difference in reliability between information provided by patients and by controls. The age of the patient recorded is that given on his first attendance. The period covered is July, 1947, to July, 1948. Some details were also noted from the case-sheets of a further 2,000 patients who attended the department between 1943 and 1947.

(b) Controls.-Information was obtained from a series of 500 controls, matched for age, sex, and social class, who were selected from the general in-patients of the hospital. Patients referred for a psychiatric opinion while in hospital were rejected, as were all patients admitted for skin and neurological disorders. It took much longer to amass the requisite number of controls because at the outset the extreme difference in agedistribution between the two types of patient was unsuspected. The period covered in collecting information about the control series was from December, 1947, to March, 1949.

Data.-The information recorded for both groups was as follows:

Propositus: Age, sex, marital status, birth rank.

Mother: Age at birth of propositus; if dead, age at death and year of death.

Father: $\quad$ Age at birth of propositus; if dead, age at death and year of death.

Family Size: At the time of the enquiry all families are believed to have been complete. 
TABLE 1

NUMBERS OF PATIENTS AND CONTROLS* AT DIFFERENT BIRTH RANKS AND MATERNAL AGES

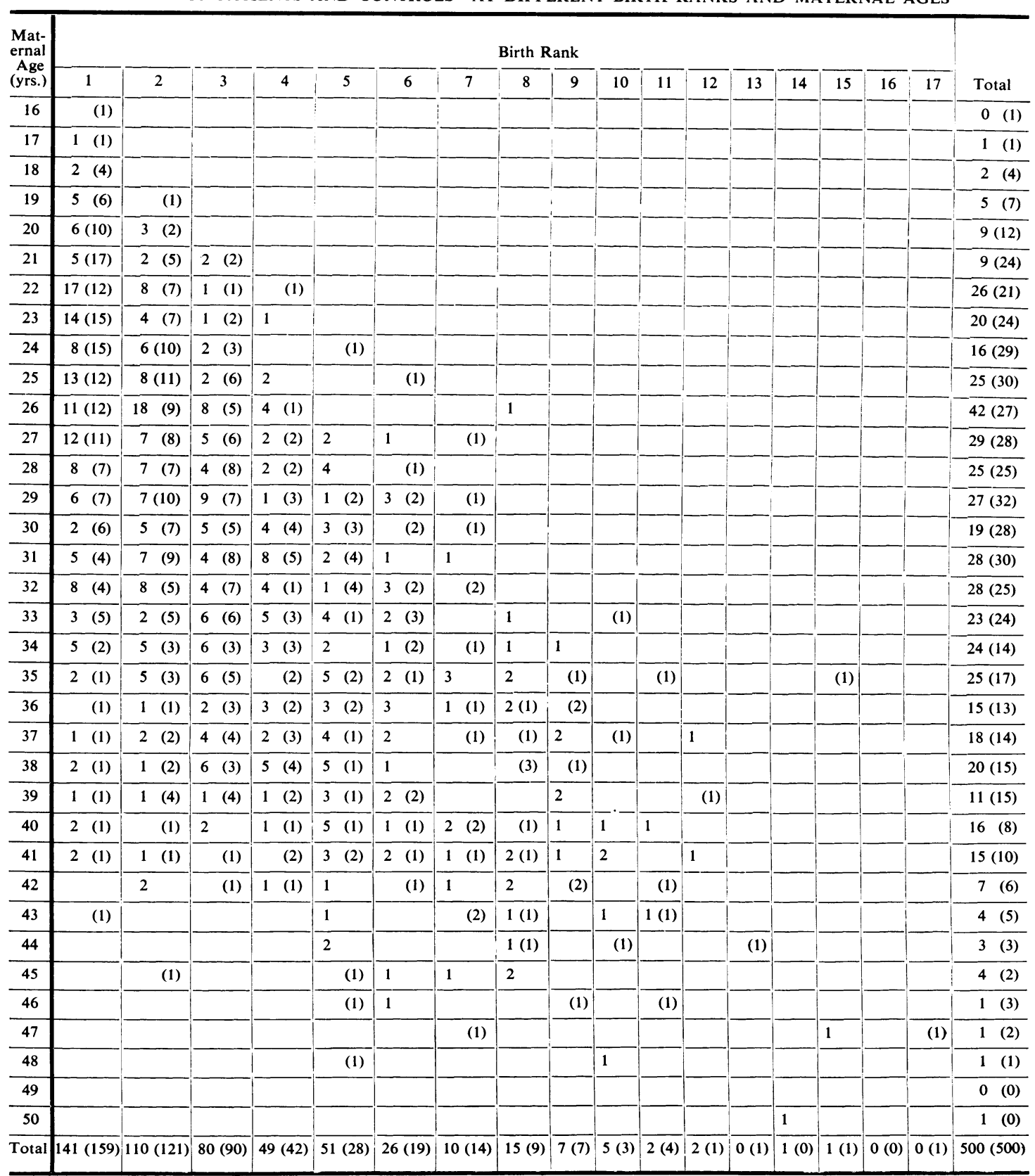


Other information, of perhaps greater interest to the psychiatrist (for example-family history, social conditions in the home, emotional relationships, early life, etc.), was excluded because of doubt about its reliability.

\section{Maternal Age and Birth Order}

Table I (opposite) distributes of patients and controls by maternal age and birth rank. Table II shows that the proportion of patients in the upper birth ranks is greater than in the case of controls. Table III shows that the proportion of patients born to mothers at higher maternal ages is greater than in the case of the controls.

Birth rank and maternal age are, of course, highly correlated and an attempt was made to separate the association between the two variables by examination of distributions

(a) at different birth ranks when maternal age is fixed,

(b) at different maternal ages when birth rank is fixed.

On the whole the association with maternal age was more definite than the association with birth rank, but the results are inconclusive.

TABLE II

DISTRIBUTIONS BY BIRTH RANK

\begin{tabular}{|c|c|c|c|c|c|}
\hline \multirow{2}{*}{$\begin{array}{l}\text { Birth } \\
\text { Rank }\end{array}$} & \multicolumn{2}{|c|}{ Patients } & \multicolumn{2}{|c|}{ Controls } & \multirow{2}{*}{$\begin{array}{l}\text { Difference } \\
(a)-(b)\end{array}$} \\
\hline & Number & $\begin{array}{l}\text { Per cent. } \\
(\text { a })\end{array}$ & Number & $\begin{array}{l}\text { Per cent. } \\
\text { (b) }\end{array}$ & \\
\hline $\begin{array}{l}1 \\
2 \\
3\end{array}$ & $\begin{array}{r}141 \\
110 \\
80\end{array}$ & $66 \cdot 2$ & $\begin{array}{r}159 \\
121 \\
90\end{array}$ & $74 \cdot 0$ & $-7 \cdot 8 \pm 2 \cdot 9$ \\
\hline $\begin{array}{c}4 \\
5 \\
6 \text { and over }\end{array}$ & $\begin{array}{l}49 \\
51 \\
69\end{array}$ & $33 \cdot 8$ & $\begin{array}{l}42 \\
28 \\
60\end{array}$ & $26 \cdot 0$ & $7 \cdot 8 \pm 2 \cdot 9$ \\
\hline Total & 500 & 100 & 500 & 100 & \\
\hline
\end{tabular}
for controls $(4 \cdot 8)$.
The data recorded included family size as well as the birth rank of the propositus, and since almost all the sibships were believed to be complete the opportunity was taken to examine the association with birth order by the method of Greenwood and Yule (1914). As controls are unnecessary in this case, all the 2,500 patients for whom this information was recorded have been included. The association with maternal age cannot be examined in the same way because the mother's age at the birth of siblings was not noted.

Table IV gives the distribution of 2,500 patients by birth rank and size of family. Table $\mathrm{V}$ (overleaf) confirms the result noted in Table II: the observed proportion of patients in the higher birth ranks is greater than the expected proportion.

The Greenwood-Yule method has also been applied to the 500 controls. This confirms that they are evenly distributed between different birth ranks:

$$
\chi^{2}=2 \cdot 15: n=5: 0 \cdot 8<P<0.9
$$

TABLE III

DISTRIBUTIONS BY MATERNAL AGE

\begin{tabular}{|c|c|c|c|c|c|}
\hline \multirow{2}{*}{$\begin{array}{c}\text { Maternal } \\
\text { Age } \\
\text { (yrs.) }\end{array}$} & \multicolumn{2}{|c|}{ Patients } & \multicolumn{2}{|c|}{ Controls } & \multirow{2}{*}{$\begin{array}{l}\text { Difference } \\
(a)-(b)\end{array}$} \\
\hline & Number & $\begin{array}{l}\text { Per cent. } \\
\text { (a) }\end{array}$ & Number & $\begin{array}{l}\text { Per cent. } \\
\quad(b)\end{array}$ & \\
\hline $\begin{array}{c}\text { Under } 23 \\
23-27 \\
28-32\end{array}$ & $\begin{array}{r}52 \\
132 \\
127\end{array}$ & $62 \cdot 2$ & $\begin{array}{r}70 \\
138 \\
140\end{array}$ & $69 \cdot 6$ & $-7 \cdot 4 \pm 3 \cdot 0$ \\
\hline $\begin{array}{c}33-37 \\
38-42 \\
43 \text { andover }\end{array}$ & $\begin{array}{r}105 \\
69 \\
15\end{array}$ & $37 \cdot 8$ & $\begin{array}{l}82 \\
54 \\
16\end{array}$ & $30 \cdot 4$ & $7 \cdot 4 \pm 3 \cdot 0$ \\
\hline Total & 500 & 100 & 500 & 100 & \\
\hline
\end{tabular}

TABLE IV

DISTRIBUTION OF 2,500 PATIENTS ACCORDING TO BIRTH RANK AND SIZE OF FAMILY

\begin{tabular}{|c|c|c|c|c|c|c|c|c|c|c|c|c|c|c|c|c|c|c|c|c|}
\hline \multirow{2}{*}{$\begin{array}{l}\text { Birth } \\
\text { Rank }\end{array}$} & \multicolumn{19}{|c|}{ Size of Family } & \multirow{2}{*}{ Total } \\
\hline & 1 & 2 & 3 & 4 & 5 & 6 & 7 & 8 & 9 & 10 & 11 & 12 & 13 & 14 & 15 & 16 & 17 & 18 & 19 & \\
\hline $\begin{array}{r}1 \\
2 \\
3 \\
4 \\
5 \\
6 \\
7 \\
8 \\
9 \\
10 \\
11 \\
12 \\
13 \\
14 \\
15 \\
16 \\
17\end{array}$ & 226 & $\begin{array}{l}172 \\
186\end{array}$ & $\begin{array}{l}124 \\
128 \\
122\end{array}$ & $\begin{array}{l}89 \\
90 \cdot 5 \\
77 \cdot 5 \\
91\end{array}$ & $\begin{array}{l}41 \\
59 \\
72 \cdot 5 \\
73 \cdot 5 \\
89\end{array}$ & $\begin{array}{l}36 \\
32 \\
39 \\
37 \\
40 \\
41\end{array}$ & $\begin{array}{l}24 \\
26 \\
16 \\
21 \\
24 \\
32 \\
35\end{array}$ & $\begin{array}{l}11 \\
11 \\
18 \\
20 \\
17 \\
19 \\
22 \\
21\end{array}$ & $\begin{array}{r}11 \\
10 \\
11 \\
7 \\
19 \\
12 \\
16 \\
14 \\
18\end{array}$ & $\begin{array}{r}6 \\
4 \\
4 \\
8 \\
13 \\
9 \\
10 \\
6 \\
7 \\
17\end{array}$ & $\begin{array}{l}5 \\
1 \\
4 \\
4 \\
3 \\
0 \\
2 \\
3 \\
3 \\
3 \\
5\end{array}$ & $\begin{array}{l}0 \\
2 \\
2 \\
1 \\
0 \\
5 \\
1 \\
3 \\
3 \\
3 \\
8 \\
2\end{array}$ & $\begin{array}{l}2 \\
4 \\
1 \\
1 \\
2 \\
0 \\
1 \\
2 \\
3 \\
1 \\
0 \\
2 \\
6\end{array}$ & $\begin{array}{l}2 \\
0 \\
\mathbf{1} \\
\mathbf{0} \\
\mathbf{0} \\
\mathbf{1} \\
\mathbf{0} \\
\mathbf{1} \\
\mathbf{0} \\
\mathbf{0} \\
\mathbf{2} \\
\mathbf{1} \\
\mathbf{0} \\
\mathbf{1}\end{array}$ & $\begin{array}{l}1 \\
0 \\
1 \\
0 \\
0 \\
1 \\
0 \\
1 \\
0 \\
0 \\
0 \\
0 \\
0 \\
1 \\
4\end{array}$ & $\begin{array}{l}0 \\
0 \\
0 \\
1 \\
0 \\
1 \\
0 \\
0 \\
0 \\
0 \\
0 \\
0 \\
0 \\
0 \\
0 \\
0\end{array}$ & $\begin{array}{l}1 \\
0 \\
0 \\
0 \\
0 \\
0 \\
0 \\
0 \\
0 \\
0 \\
0 \\
0 \\
0 \\
0 \\
0 \\
1 \\
1\end{array}$ & $\begin{array}{l}0 \\
0 \\
0 \\
2 \\
0 \\
0 \\
0 \\
1 \\
0 \\
0 \\
0 \\
0 \\
0 \\
0 \\
0 \\
0 \\
0\end{array}$ & $\begin{array}{l}0 \\
0 \\
0 \\
0 \\
0 \\
0 \\
0 \\
0 \\
0 \\
0 \\
0 \\
0 \\
0 \\
0 \\
0 \\
0 \\
1\end{array}$ & $\begin{array}{l}751 \\
553 \cdot 5 \\
369 \\
266 \cdot 5 \\
207 \\
121 \\
87 \\
52 \\
34 \\
24 \\
15 \\
5 \\
6 \\
2 \\
4 \\
1 \\
2\end{array}$ \\
\hline Total & 226 & 358 & 374 & 348 & 335 & 225 & 178 & 139 & 118 & 84 & 33 & 30 & 25 & 9 & 9 & 2 & 3 & 3 & 1 & 2,500 \\
\hline
\end{tabular}

The decimal places are due to twins, which have been allocated as 0.5 to each of two successive birth ranks. 
TABLE V

EXPECTED AND OBSERVED DISTRIBUTIONS BY BIRTH RANK OF 2,500 PATIENTS (Greenwood-Yule Method)

\begin{tabular}{c|c|c}
\hline \multirow{2}{*}{$\begin{array}{c}\text { Birth } \\
\text { Rank }\end{array}$} & Expected & Observed \\
\cline { 2 - 3 } 1 & $793 \cdot 8$ & 751 \\
2 & $572 \cdot 8$ & $553 \cdot 5$ \\
3 & $388 \cdot 8$ & 369 \\
4 & $264 \cdot 2$ & $266 \cdot 5$ \\
5 & $177 \cdot 2$ & 207 \\
6 and over & $303 \cdot 5$ & 353 \\
\hline Total & $2,500 \cdot 3$ & 2,500 \\
\hline & & \\
\hline & $\chi^{2}=17 \cdot 07, \quad n=5, \quad P<0 \cdot 01$
\end{tabular}

A subject of additional interest is the possible association between the incidence of neurosis and position in family (as distinct from birth order). Table VI shows no difference to exist between patients and controls either in the proportion of only children, or in the proportions of eldest, intermediate, and youngest children in families with more than one child.

\section{TABLE VI}

DISTRIBUTIONS OF PATIENTS AND CONTROLS ACCORDING TO POSITION IN FAMILY

\begin{tabular}{|c|c|c|c|}
\hline \multirow{2}{*}{$\begin{array}{l}\text { Position of } \\
\text { Child } \\
\text { in Family }\end{array}$} & \multicolumn{2}{|c|}{ Per cent. } & \multirow{2}{*}{$\begin{array}{l}\text { Difference } \\
(a)-(b)\end{array}$} \\
\hline & $\begin{array}{l}\text { Patients } \\
\quad(a)\end{array}$ & $\begin{array}{c}\text { Controls } \\
\text { (b) }\end{array}$ & \\
\hline $\begin{array}{l}\text { Only } \\
\text { Eldest } \\
\text { Youngest } \\
\text { Intermediate }\end{array}$ & $\begin{array}{r}9 \cdot 0 \\
19 \cdot 2 \\
25 \cdot 0 \\
46 \cdot 8\end{array}$ & $\begin{array}{r}8 \cdot 4 \\
23 \cdot 4 \\
24 \cdot 7 \\
43 \cdot 5\end{array}$ & $\begin{array}{r}0.6 \pm 1.8 \\
-4.2 \pm 2.6 \\
0.3 \pm 2.7 \\
3.3 \pm 3.1\end{array}$ \\
\hline Total & $\begin{array}{c}100 \\
(500)\end{array}$ & $\begin{array}{c}100 \\
(500)\end{array}$ & \\
\hline
\end{tabular}

As might be expected in view of the correlation between mother's and father's age, the proportion of patients with older fathers is slightly higher than for the controls.

The difference in age between the parents has also been found to be somewhat greater for the patients than for the controls, a conclusion similar to that of Glueck and Glueck (1934), Thurstone and Jenkins (1931), and Doshay (1943) in investigating groups of juvenile delinquents.

\section{Loss of a Parent}

Table VII shows that:

(1) There is no difference between the proportion of patients who had lost a parent and the proportion of controls.

(2) A significantly higher proportion of patients had lost a father before they were ten years old.

(3) There is no significant difference between the age of patients at loss of mother and that of controls.
TABLE VII

AGE OF PROPOSITI AT DEATH OF PARENTS

\begin{tabular}{|c|c|c|c|c|c|c|}
\hline \multirow{2}{*}{$\begin{array}{c}\text { Age at } \\
\text { Parents' } \\
\text { Death } \\
\text { (yrs) }\end{array}$} & \multicolumn{3}{|c|}{ Father (Per cent.) } & \multicolumn{3}{|c|}{ Mother (Per cent.) } \\
\hline & $\begin{array}{c}\text { Patients } \\
\text { (a) }\end{array}$ & $\begin{array}{l}\text { Con- } \\
\text { trols } \\
(b)\end{array}$ & $\begin{array}{l}\text { Difference } \\
(a)-(b)\end{array}$ & $\begin{array}{c}\text { Patients } \\
\text { (a) }\end{array}$ & $\begin{array}{l}\text { Con- } \\
\text { trols } \\
(b)\end{array}$ & $\begin{array}{c}\text { Difference } \\
(a)-(b)\end{array}$ \\
\hline $\begin{array}{c}0-4 \\
5-9 \\
10-14 \\
15-19 \\
20 \text { and }\end{array}$ & $\begin{array}{l}3 \cdot 8 \\
4 \cdot 8 \\
3 \cdot 8 \\
3 \cdot 2\end{array}$ & $\begin{array}{l}1 \cdot 4 \\
2 \cdot 4 \\
3 \cdot 8 \\
5 \cdot 4\end{array}$ & $\begin{array}{r}2 \cdot 4 \\
2 \cdot 4 \cdot 0 \\
0 \cdot 0 \\
-2 \cdot 2 \cdot 2 \\
-1 \cdot 3\end{array}$ & $\begin{array}{l}2 \cdot 0 \\
1 \cdot 6 \\
2 \cdot 6 \\
3 \cdot 8\end{array}$ & $\begin{array}{l}2 \cdot 2 \\
1 \cdot 8 \\
3 \cdot 2 \\
2 \cdot 8\end{array}$ & $\begin{array}{r:r}-0.2 & 0.9 \\
-0.2 & 0.8 \\
-0.6 & 1.0 \\
1.0 & 1.1\end{array}$ \\
\hline over & $26 \cdot 4$ & $27 \cdot 2$ & $-6 \cdot 8 \pm 2 \cdot 8$ & $18 \cdot 2$ & $16 \cdot 2$ & $2 \cdot 0 \longleftarrow 2 \cdot 4$ \\
\hline Total & $42 \cdot 0$ & $40 \cdot 2$ & $1 \cdot 8 \pm 3 \cdot 1$ & $28 \cdot 2$ & $26 \cdot 2$ & $2 \cdot 0 \div 2 \cdot 8$ \\
\hline $\begin{array}{r}\text { Parent } \\
\text { alive }\end{array}$ & $58 \cdot 0$ & $59 \cdot 8$ & $-1 \cdot 8 \pm 3 \cdot 1$ & $71 \cdot 8$ & $73 \cdot 8$ & $-2 \cdot 0-2 \cdot 8$ \\
\hline Total & $\begin{array}{c}100 \\
(500)\end{array}$ & $\begin{array}{c}100 \\
(500)\end{array}$ & & $\begin{array}{c}100 \\
(500)\end{array}$ & $\begin{array}{c}100 \\
(500)\end{array}$ & \\
\hline
\end{tabular}

Fourteen patients and eleven controls had lost both parents before reaching the age of twenty. No difference was found between patients and controls in the age at which this loss had occurred.

These conclusions are surprising. The field covered by the literature is considerably wider and deals chiefly with the relationship between the "broken home" situation and such groups as juvenile delinquents and psychopathic characters.

Bowlby (1951), for example, who has recently marshalled all the evidence, concludes firmly that there is a close relationship between early maternal deprivation and the development of affectionless characters. Barry (1939), too, in a psychotic group, found that the incidence of maternal deaths but not of paternal deaths, was higher than in the general population. Of a group of neurotic soldiers, Madow and Hardy (1947) found that 21 per cent. had lost one or both parents before the age of sixteen, loss of father being just as frequent as loss of mother. The lack of controls in these studies is a serious drawback, but the Statistical Bulletin of the Metropolitan Life Insurance Company (1944) states that 16.7 per cent. of the population of the United States have lost one or both parents before the age of eighteen. In the present series, $14 \cdot 2$ per cent. of the controls had lost one or both parents before the age of fifteen, a figure in accordance with that quoted for the American population.

The conclusions to be drawn from Table VII lend no support to the view that early loss of the mother is a cause of psychiatric abnormality in neurotic patients. The high figure for early loss of the father may perhaps conceal a higher rate of illegitimacy in patients than in controls, but it suggests that it is economic insecurity rather than emotional deprivation which is harmful. 


\section{Discussion}

The examination conducted here of a group of neurotic patients and of a group of controls leads to the conclusion that there is an association between neurosis and the higher birth ranks (four and upwards) and the higher maternal ages (33 and upwards). As regards maternal age there seem to be no comparable published figures, though Marro (1912) reported that both very young and very old parents tended to have more criminal and insane children than parents of between 21 and 36 .

As regards the relation between birth rank and neurosis, Abernethy (1940) reported that first-born children were less neurotic than those born later. This conclusion is contrary to that of Pearson (1914) who was of the opinion that the later members of the family after the first and second were sounder both mentally and physically.

Most authors who have written on this topic have, however, been less concerned with birth rank than with "position in family". Its importance in moulding character has been emphasized by many, particularly those of the Adlerian school. In this literature each position is linked with particular traits. For example, Adler (1928) remarks that the only child searches for support at all times; Wexberg (1930) says that the eldest may "carry the gesture of a dethroned monarch for the rest of its life"; Hill (1945) says that the youngest shows a striving for power, or else evades duties and responsibilities and retreats.

Most of these authors are not content to confine their generalizations solely to character traits, and assert that position in family also predisposes to neurosis and behaviour disorder. The negative findings of the present enquiry shown in Table VI are opposed by such statements as these:

Wexberg (1930): Only children "whether as children or as adults constitute a large percentage of a psychiatrist's patients".

Hill (1945) of eldest children: "A large proportion develop into problem children," and "a large number of youngest children fill the ranks of problem children, neurotics, and criminals."

Brill (1922): "It would be best for the individual as well as the race that there should be no only children", and "only childism is a bad disease".

These views are based on long clinical experience and not upon controlled enquiry.

Several authors, however, report negative findings:

Fenton (1928) could find no reliable trait differences between various birth positions, nor significant correlation between birth order and emotional abnormality in groups of American college students.
Stuart (1926) in a similar investigation found no evidence at all in favour of the hypothesis of emotional instability of the only child.

Thurstone and Thurstone (1930) remarked that "birth order is not so universally important a consideration in mental hygiene as is sometimes believed.

The evidence presented in this paper implies that the decrease in the average size of the family in the past hundred years, which has reduced the numbers born in the higher birth ranks, may well have diminished in consequence the number of people prone to develop neurotic illness. Despite much medical and lay opinion to the contrary, there seems no reason to believe that the concomitant increase in the proportion of those born into a special position in the family-only, eldest, or youngest-has been harmful.

\section{SUMmaRY}

(1) A comparison of 500 psychiatric patients with 500 controls matched for age, sex, and social class shows that a larger proportion of patients than of controls were in the higher birth ranks.

(2) The proportion of patients born to mothers at higher maternal ages was greater than in the case of the controls.

(3) An examination of the patients' sibships, together with the sibships of a further 2,000 patients, was made by the Greenwood-Yule method. It confirms that the observed proportion of patients in the higher birth ranks was greater than the expected proportion.

(4) No difference was found between 500 patients and 500 controls in the proportion who were only, eldest, youngest, or intermediate children.

(5) Equal proportions of patients and controls had lost a parent; but a significantly higher proportion of patients had lost a father before the age of ten. No such difference was found in the age at loss of mother.

My thanks are due to Dr. Henry Wilson for his interest and encouragement; to Dr. P. H. Tooley and the other members of the staff of the Psychiatric Department of the London Hospital, both medical and lay, for help in collecting the data; to the staff of the Almoner's Department of the London Hospital, in particular to Miss Mary Wise, for collecting the control data.

\section{REFERENCES}

Abernethy, E. M. (1940). J. Psychol., 10, 303

Adler, A. (1928). "Understanding Human Nature", trans. W. B. Wolfe, p. 84 et seq. Allen and Unwin, London.

Barry, H. (1939). Amer. J. Orthopsychiat., 9, 355.

Bowlby, J. (1951). "Maternal Care and Mental Health". World Health Organization, Geneva. 
Brill, A. A. (1922). "Psychoanalysis-its theories and practical application", 3rd ed. Saunders, Philadelphia.

Doshay, L. J. (1943). "The Boy Sex Offender and his Later Career". Grune and Stratton, New York.

Fenton, N. (1928). J. Genet. Psychol., 35, 546.

Glueck, S. S., and Glueck, E. T. (1934). "i,000 Juvenile Delinquents". Harvard University Press, Cambridge, Mass.

Greenwood, M., and Yule, G. U. (1914). J. roy. statist. Soc., 77, 179.

Hill, T. W. (1945). Med. Off., 73, 176

Holmes, S. J. (1921). "The Trend of the Race." Constable, London.

Holmes, S. J. (1921). "The Trend of the Race." Con
Hsiao, H. H. (1931). Genet. Psychol. Monogr., 9, 1.

Jones, H. E. (1933). In "A Handbook of Child Psychology", 2nd. ed., ch. 13. Ed. C. Murchison. Clark University Press, Worcester, Mass.

Madow, L., and Hardy, S. E. (1947). Amer. J. Orthopsychiat., 17, 521.

Malzberg, B. (1950). Amer. J. Ment. Defic., 54, 266.

Marro, A. (1912). "Problems in Eugenics": Report of First International Eugenics Congress, pp. 118-136. London.

McKeown, T., MacMahon, B., and Record, R. G. (1951). Ann. Eugen., Lond., 16, 249.
Metropolitan Life Insurance Company (1944). Statist. Bull., 25, No. 3, p. 3.

Miller, E. (1944). In "Mental Abnormality and Crime", pp. 227-237. "English Studies in Criminal Science", vol. 2, ed. L. Radzinowicz, and J. W. C. Turner. Macmillan, London.

Pearson, K. (1914). "On the Handicapping of the First-born." Eugenics Lecture Series, No. 10. Dulau, London.

Penrose, L. S. (1934). Proc. roy. Soc. B., 115, 431.

Report of Royal Commission on Population (1949). Cmd. 7695, H.M.S.O., London.

Still, G. F. (1927). Lancet, 2, 795 and 853.

Stuart, J. C. (1926). J. abnorm. Psychol., 20, 441.

Thurstone, L. L., and Jenkins, P. L. (1931). "Order of Birth, ParentAge, and Intelligence". Behavior Research Fund Monograph. University of Chicago Press.

- - and Thurstone, T. G. (1930). J. soc. Psychol., 1, 3.

Wexberg, E. (1930). "Individual Psychology", trans. W. B. Wolfe. Allen and Unwin, London. 